\title{
TREATMENT OF SPONTANEOUS PNEUMOTHORAX
}

\author{
BY \\ WILliAM G. SMITH* AND PETER P. G. ROTHWELL $\dagger$ \\ From Sully Hospital (Thoracic Centre), Penarth, Glamorgan
}

The term pneumothorax was first used by Itard in 1803, and in 1826 Laennec first described the clinical features. For many years spontaneous pneumothorax was thought to be tuberculous in origin, and as late as 1931 Palmer and Taft reviewed 70 published cases and added five of their own. They stated that the cause was ulceration of the visceral pleura by a subpleural tuberculous focus in 80 to $90 \%$ of adults and in 40 to $50 \%$ of children.

Kjaergaard (1932), in an important study, described 51 patients followed for three to 18 years. He stressed that few of these patients had cough, sputum, pyrexia, or other evidence of pulmonary tuberculosis, and this disease subsequently developed in only one of 49 patients. He thought that the pneumothorax resulted from the rupture of a non-tuberculous air vesicle or bleb and suggested the term "pneumothorax simplex" for the occurrence of spontaneous pneumothorax in apparently healthy individuals. This opinion has been confirmed by many workers since then.

In the many papers on the subject the main points of discussion have usually centred around treatment, recurrence rates, and possible tuberculous aetiology. Interpretation is often difficult because of small numbers of patients and relatively short periods of follow-up. There are few adequate reports in which it is possible to assess any particular form of treatment. The present study is concerned mainly with the efficacy and place of iodized talc pleurodesis.

\section{Material AND Methods}

The present series consists of 150 patients admitted to hospital between 1944 and 1960 . One hundred and eighteen patients were treated in Sully Hospital, the regional thoracic centre of South Wales; 25 patients were treated in Llandough Hospital and seven in the East Glamorgan Hospital, both general hospitals in the vicinity of Cardiff. All patients were treated by the same consultant thoracic surgeons. One hundred and thirty-three patients have been traced, and these have answered a postal questionnaire and have been examined either by the authors, by the chest clinic physicians, or, in a few instances, by the family

* Now at Perth Chest Hospital, Shenton Park, Western Australia.

+ Now at Hamilton Public Hospital, New Zealand. practitioner. A 1960 chest radiograph was obtained in 133 patients. Two of the original films could not be traced. The pneumothorax was spontaneous in all cases and of the benign "simplex" variety in eightyfour. No pneumothorax was included due to gross extrapulmonary or pulmonary disease, such as pneumonia, infarction, neoplasm, honeycomb lungs, active tuberculosis, trauma, or oesophageal or subphrenic lesions.

\section{ANALYSIS}

Table I shows the composition of the series and the age and sex incidence. One man aged 70 died in hospital as a result of the pneumothorax. $\mathrm{He}$

TABLE I

SPONTANEOUS, PNEUMOTHORAX

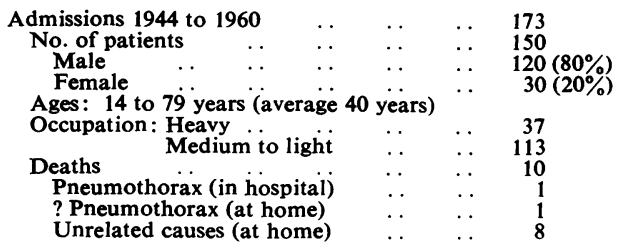

had severe obstructive emphysema with a greatly reduced respiratory reserve and died a few days after admission despite re-expansion of the lung by an intercostal tube and suction. Another patient died at home, probably from tension pneumothorax, although no necropsy was made. Of the 43 known Mantoux reactions, nine were negative.

Table II shows the age groups concerned. The rather high percentage in the 40 to 60 age group may be explained by the relatively high incidence of chronic bronchitis and emphysema in this study, as in the series of Crowther (1955).

TABLE II

AGE INCIDENCE

\begin{tabular}{lcccccccc}
\multicolumn{1}{c}{ Age } & -20 & $21-30$ & $31-40$ & $41-50$ & $51-60$ & $61-70$ & $71-80$ & Total \\
\hline $\begin{array}{l}\text { No. of patients } \\
\text { Percentage }\end{array}$ & 7 & 40 & 27 & 37 & 18 & 16 & 5 & 150 \\
& 26 & 18 & 25 & 12 & 11 & 3 & 100
\end{tabular}

Table III indicates the increased numbers of patients referred for treatment during the past five years. This reflects the trend towards more active treatment in recent years. 
TABLE III

YEAR OF FIRST HOSPITAL ADMISSION

\begin{tabular}{|c|c|c|c|c|c|c|c|c|c|c|c|c|c|c|c|c|c|}
\hline Year & 1944 & 1945 & 1946 & 1947 & 1948 & 1949 & 1950 & 1951 & 1952 & 1953 & 1954 & 1955 & 1956 & 1957 & 1958 & 1959 & 1960 \\
\hline No. of patients & 2 & 0 & 1 & 2 & 0 & 1 & 2 & 6 & 6 & 11 & 9 & 13 & 10 & 18 & 23 & 28 & 18 \\
\hline
\end{tabular}

Table IV details associated chest disease. The sputa of the eight patients with fibrocalcific upper lobe lesions were bacteriologically negative for acid-fast bacilli at the time of the pneumothorax, and only one patient had been treated previously for pulmonary tuberculosis.

\section{TABLE IV}

ASSOCIATED CHEST DISEASE

\section{Disease}

No. of Patients

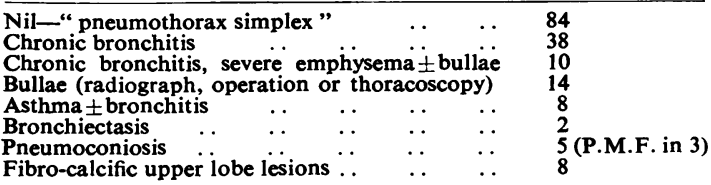

Nine patients had a chronic pneumothorax of three or more months' duration. In four patients a haemopneumothorax was present. Increased tension, as judged by clinical criteria in the pleural cavity, was present in four patients.

Table V shows the side and frequency of pneumothorax. The right side was involved more frequently than the left. Seventy-one per cent. of patients presented with the first pneumothorax.

\section{TABLE V}

SIDE AND FREQUENCY OF PNEUMOTHORAX

\begin{tabular}{|c|c|c|c|c|c|}
\hline $\begin{array}{l}\text { Right side } \\
\text { Left } \text { Single" } \\
\text { Multiple .. }\end{array}$ & $\begin{array}{l}\because \\
\because \\
\because\end{array}$ & $\begin{array}{l}\because \\
\cdots \\
\cdots\end{array}$ & $\begin{array}{l}\cdots \\
\cdots \\
\cdots\end{array}$ & $\begin{array}{l}\cdots \\
\cdots \\
\cdots\end{array}$ & $\begin{array}{l}139 \text { episodes } \\
102 \\
107(71 \%) \text { patients } \\
43(29 \%) \text { patients } \\
27 \text { unilateral } \\
15 \text { bilateral alternating } \\
1 \text { bilateral simultaneous }\end{array}$ \\
\hline
\end{tabular}

Forty-three patients $(29 \%)$ had more than one proved pneumothorax. Fifteen patients $(10 \%)$ had bilateral episodes but these were simultaneous in only one. The figure for multiple pneumothoraces is an underestimate, as probable but unproved pneumothoraces have been excluded, and some of the 17 untraced patients may have had recurrences. One patient, however, had at least 10 proved recurrences, and probably had three or four unproved episodes.

Symptoms are detailed in Table VI. It is of interest that only one patient was entirely free of symptoms, and the condition was diagnosed incidentally by a chest radiograph. Pain was less common than dyspnoea but usually preceded it. One patient presented with abdominal pain and nearly had a laparotomy for a possible perforated
TABLE VI

SYMPTOMS DURING 173 ADMISSIONS

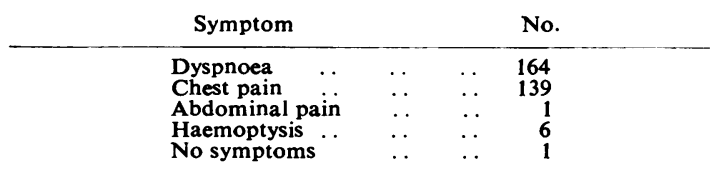

viscus. The onset of symptoms was gradual in approximately $20 \%$. In the six patients with haemoptysis, one had a fibrocalcific lesion in the right upper lobe; another had an emphysematous bulla, and no obvious cause was found in the remainder. Many patients were unable to pinpoint the onset of the attack to any particular activity, and only seven patients were undertaking strenuous effort (Table VII). It seems probable

TABLE VII

ACTIVITY AT THE TIME OF ATTACK (IF KNOWN)

\begin{tabular}{|c|c|c|c|c|c|c|}
\hline \multicolumn{3}{|l|}{ Activity } & No. & Activity & \multicolumn{2}{|r|}{ No. } \\
\hline Heavy effort & . & $\cdots$ & 7 & Getting out of bed & $\cdots$ & 2 \\
\hline Walking . . & . & $\cdots$ & 10 & Moving in bed ... & . & 2 \\
\hline Coughing & . & $\ldots$ & 5 & Cycling $\quad \ldots$ & $\ldots$ & 2 \\
\hline Driving . & . & . & 4 & Golfing & . & 2 \\
\hline Sitting & $\cdots$ & $\cdots$ & 2 & Stumbling & $\cdots$ & 1 \\
\hline Standing & . & $\ldots$ & 2 & Sneezing & $\ldots$ & i \\
\hline Eating & $\cdots$ & $\cdots$ & 1 & No unusual activity & $\cdots$ & 30 \\
\hline Not recorded & $\cdots$ & $\cdots$ & 79 & & & \\
\hline
\end{tabular}

that the symptoms of cough and sneeze may have been the result rather than the cause of pneumothorax. The radiological findings are detailed in Table VIII.

\section{TABLE VIII}

RADIOLOGICAL FINDINGS

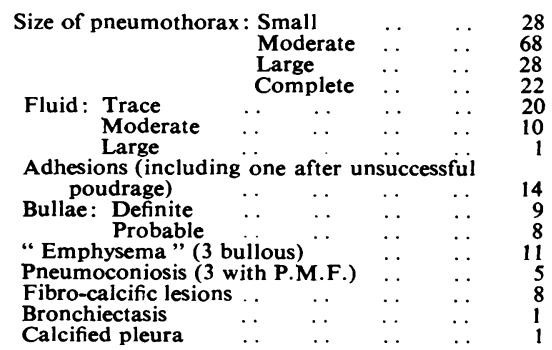

\section{TREATMENT GROUPS}

TAlc.-The method of poudrage with iodized talc insufflation combined with thoracoscopy has been used at Sully Hospital since 1950 in a total of 62 patients, 20 of whom had previous pneumothoraces. General anaesthesia has always been 
used, and, as with any other technical procedure, care and skill are important in the successful use of this method of treatment. Two intercostal cannulae are inserted, one in the second interspace anteriorly and the other in the sixth or seventh interspace in the axilla. After thoracoscopy and inspection of the collapsed lung, 2 to $5 \mathrm{~g}$. of $1 \%$ iodized talc is insufflated widely and evenly through both cannulae: a satisfactory spread is confirmed by repeat thoracoscopy. An intercostal catheter is inserted through the lower cannula and allowed to drain with an underwater seal.

If the lung does not expand immediately, suction is required. The catheter is removed 48 to 72 hours after lung expansion is radiologically complete, depending on the amount of drainage. The average period of intubation in this series was just over three days. Careful management of the catheter is essential for the success of the method. Active breathing exercises and posture on the normal side are started as soon as the intercostal tube is removed. In some patients a fair degree of pain followed recovery of consciousness, and pethidine or other analgesic was sometimes needed more than once, though most patients did not have much pain. One patient had an iodine hypersensitivity reaction six days after poudrage. Most patients had a mild or moderate pyrexial reaction lasting four to seven days. Variable, but usually small, amounts of fluid have been drained by the intercostal tube, in a few instances amounting to over one litre, indicating a marked pleural reaction. Very occasionally aspiration of fluid has been necessary after removal of the intercostal tube, since usually the pleural reaction rapidly clears on the radiograph, and within a few weeks very little fluid can be seen in the pleural space. Within a few months there is usually little radiological evidence of the previous poudrage. After six months, in 19 patients there was no significant radiographic change: this included one patient who had had bilateral thoracoscopy and poudrage. In 25 patients there was a slight degree of obliteration of the costophrenic angle. In 15 patients the changes were moderate, and in only two was pleural thickening and elevation of the diaphragm fairly marked.

Lesions seen at thoracoscopy included bullae in six cases, adhesions in two, a doubtful caseous lesion in one, and the "cuckoo spit" appearance described by Brock (1948) in one.

BED REST.-Forty-four patients had bed rest without any active treatment. The majority of these patients had shallow pneumothoraces.
INTERCostal TUBE.-Eighteen patients were treated with an intercostal catheter, with or without suction. The tube was usually inserted anteriorly in the second space or high in the axilla just behind the pectoral fold. In one patient fresh tubes had to be re-inserted on 12 different occasions due to a recurrence of pneumothorax after removal of the tube or to technical difficulties.

ThORAcoTomy.-Fourteen patients had major surgery. In five patients thoracotomy was advised because of large bullae or cysts seen by the thoracoscope or radiographically. Excision and oversewing of bullae was performed in these patients. Two patients had decortication because of chronic pneumothorax and a third because of an empyema following a previous camphor pleurodesis. Another patient had decortication and poudrage with iodized talc following an infected haemopneumothorax. One patient had parietal pleurectomy. Four patients had a thoracotomy with slight mechanical scarification of the lungs and iodized talc poudrage ; in two numerous small bullae were seen, but in the other two no cause of pneumothorax was evident.

Camphor.-Camphor pleurodesis $\left(\frac{1}{2}\right.$ to $1 \%$ camphor in oil) using a syringe and needle was performed in six patients. One patient had two separate injections on one side and one further injection on the other side.

Silver Nitrate.-Silver nitrate was tried initially but discontinued because of the severity of local pain.

\section{RESULTS}

Table IX shows the results in the different treatment groups correlated with average stay in hospital and incidence of previous pneumothoraces. Six patients are not included in these treatment groups as they were treated with silver nitrate pleurodesis or had air aspirations in addition to bed rest.

Table $\mathrm{X}$ shows the period of follow-up in each group. Sixty-one of the 62 patients treated with iodized talc have been traced. Three patients $(5 \%)$ have had recurrences five years, 21 months, and one month after treatment. In the first patient, the intercostal tube was removed after 24 hours, thereby allowing the fairly large reactive effusion to keep the pleural layers apart, so vitiating the effects of the pleural irritation. The second patient had an unusual minute recurrence in the horizontal fissure 21 months after poudrage. A thin, 
TABLE IX

TREATMENT GROUPS, HOSPITAL STAY, PREVIOUS PNEUMOTHORACES, AND RECURRENCES

\begin{tabular}{|c|c|c|c|c|c|c|}
\hline \multirow[b]{2}{*}{ Method of Treatment } & \multirow[b]{2}{*}{$\begin{array}{l}\text { No. of } \\
\text { Patients }\end{array}$} & \multirow[b]{2}{*}{$\begin{array}{l}\text { No. of } \\
\text { Patients } \\
\text { Traced }\end{array}$} & \multirow{2}{*}{$\begin{array}{c}\text { Average } \\
\text { Stay in } \\
\text { Hospital in Days }\end{array}$} & \multicolumn{2}{|c|}{ Previous Pneumothoraces } & \multirow[b]{2}{*}{$\begin{array}{c}\text { Known } \\
\text { Recurrences }\end{array}$} \\
\hline & & & & $\begin{array}{l}\text { Same } \\
\text { Side }\end{array}$ & $\begin{array}{l}\text { Opposite } \\
\text { Side }\end{array}$ & \\
\hline $\begin{array}{l}\text { All types } \\
\text { Thoracoscopy and poudrage }\end{array}$ & 150 & 133 & $32 \cdot 0$ & 30 & 13 & $14(9 \%)$ \\
\hline $\begin{array}{l}\text { (iodized talc) } \\
\text { Bed rest only } \\
\text { Intercostal tube } \pm \text { suction } \\
\text { Thoracotomy } \\
\text { Camphor pleurodesis }\end{array}$ & $\begin{array}{r}62 \\
44 \\
18 \\
14 \\
6\end{array}$ & $\begin{array}{r}61 \\
29 \\
18 \\
13 \\
6\end{array}$ & $\begin{array}{l}28 \cdot 7 \\
33 \cdot 4 \\
30 \cdot 7 \\
45 \cdot 2 \\
33 \cdot 8\end{array}$ & $\begin{array}{r}15 \\
4 \\
2 \\
3 \\
5\end{array}$ & $\begin{array}{l}5 \\
0 \\
3 \\
2 \\
0\end{array}$ & $\begin{array}{l}3(5 \%) \\
5(9 \%) \\
3(17 \%) \\
1(7 \%) \\
2(33 \%)\end{array}$ \\
\hline
\end{tabular}

TABLE X

DURATION OF FOLLOW-UP

Follow-up (Years)

\begin{tabular}{|c|c|c|c|c|c|c|c|c|c|c|c|c|c|c|c|c|c|c|c|}
\hline Method & $0_{\frac{1}{2}}$ & $\frac{1}{2}-1$ & $\begin{array}{l}1- \\
1 \frac{1}{2}\end{array}$ & $\frac{1+}{2}-$ & $2-$ & ${ }^{3-}$ & $\sqrt[4]{5}$ & $\frac{5-}{6}$ & $\frac{6-}{7}$ & $\overline{8}$ & $\stackrel{8-}{9}$ & $\begin{array}{l}9- \\
10\end{array}$ & $\begin{array}{l}10- \\
11\end{array}$ & $\begin{array}{l}11- \\
12\end{array}$ & $13^{12-}$ & $\begin{array}{l}13- \\
14\end{array}$ & $\begin{array}{l}14 \\
15\end{array}$ & $\begin{array}{l}15- \\
16\end{array}$ & Mean \\
\hline $\begin{array}{l}\text { Thoracoscopy and poudrage } \\
\text { Bed rest only } \\
\text { Intercostal tube } \\
\text { Thoracotomy } \\
\text { Camphor pleurodesis } \\
\text { Chronic pneumothorax }\end{array}$ & $\begin{array}{l}4 \\
0 \\
2 \\
2 \\
0 \\
0\end{array}$ & $\begin{array}{l}9 \\
1 \\
5 \\
0 \\
0 \\
0\end{array}$ & $\begin{array}{l}4 \\
1 \\
1 \\
2 \\
0 \\
1\end{array}$ & $\begin{array}{r}14 \\
2 \\
2 \\
2 \\
0 \\
0\end{array}$ & $\begin{array}{r}12 \\
4 \\
1 \\
0 \\
0 \\
0\end{array}$ & $\begin{array}{l}6 \\
4 \\
3 \\
2 \\
0 \\
0\end{array}$ & $\begin{array}{l}8 \\
2 \\
1 \\
0 \\
3 \\
0\end{array}$ & $\begin{array}{l}3 \\
5 \\
1 \\
3 \\
1 \\
1\end{array}$ & $\begin{array}{l}0 \\
5 \\
2 \\
0\end{array}$ & $\begin{array}{l}1 \\
2 \\
2\end{array}$ & $\begin{array}{l}\mathbf{0} \\
\mathbf{0}\end{array}$ & $\begin{array}{l}1 \\
0\end{array}$ & 0 & 0 & 2 & 0 & 0 & 1 & $\begin{array}{l}2 \cdot 8 \\
5 \cdot 4 \\
2 \cdot 5 \\
4 \cdot 7 \\
4 \cdot 8 \\
9 \cdot 1\end{array}$ \\
\hline
\end{tabular}

transverse, translucent area was visible on the chest radiograph following an episode of slight right chest pain and had disappeared on a repeat film taken a few days later. This trivial recurrence implied good pleural adhesion elsewhere. In the third patient technical reasons for insufficient poudrage, noted at the time, could well be held responsible for the recurrence. A satisfactory repeat poudrage was performed one month later, and there has been no recurrence during the subsequent year. A fourth patient is not included as a recurrence because lung expansion after poudrage was never achieved due to technical difficulties with the intercostal tube and suction. Thoracotomy was performed 16 days after poudrage. Apart from the two patients noted above, poudrage was performed on the one occasion only.

In the bed-rest series, only 29 of the 44 patients have been traced. Five $(9 \%)$ recurrences have developed. Subsequently three had further periods of bed rest and two had thoracotomies.

Three of the 18 cases treated by intercostal tube had recurrences. Subsequently one was treated by bed rest, one had poudrage with iodized talc, and the other had a right pulmonary resection for pulmonary tuberculosis, followed a few months later by a left thoracotomy and poudrage for recurrent left pneumothorax.

One patient treated by thoracotomy and excision of bullae had a recurrence approximately one year later, which was treated by bed rest at home. It is not known whether this occurred on the same or opposite side. He has remained well for five years since the second episode.
The results of camphor pleurodesis (six cases) were unimpressive. One had to have a thoracotomy because of subsequent empyema. Of the remainder, one patient, after bilateral camphor injections, continued to have recurrences and had thoracotomy for pulmonary tuberculosis on one side and a thoracotomy and poudrage on the other. Another patient had a recurrence on the same side three years later and was treated by thoracoscopy and poudrage. In addition to camphor pleurodesis, he had been treated for haemopneumothorax on the same side two years earlier. Despite these two episodes, the pleura was obviously not adherent.

Table XI shows the details of the recurrences. Table IX shows that the poudrage group had a much higher incidence of previous episodes than the other groups. In addition, the pneumothorax was more often large, which frequently indicates a larger air leak.

HaEmopneumothoraces (4 cases).-One patient was treated by thoracotomy at the time of the initial episode. One had thoracotomy later because of a chronic pneumothorax. One patient was treated by intercostal tube and one by aspiration and blood transfusion. None of these patients has had a recurrence to date.

Chronic Pneumothoraces (9 cases).-The details are shown in Table XII. Thoracotomy was performed in only two of the nine cases. The others were treated by bed rest and air aspiration (3) ; by aspiration, thoracoscopy, and poudrage with silver nitrate and kaolin (2); and by intercostal tube and high suction in the remainder (2). 
TABLE XI

ANALYSIS OF RECURRENCES

\begin{tabular}{|c|c|c|c|c|c|c|}
\hline $\begin{array}{l}\text { No. of } \\
\text { Patients }\end{array}$ & Method & $\begin{array}{l}\text { Patient } \\
\text { Recur- } \\
\text { rences }\end{array}$ & $\begin{array}{l}\text { Interval } \\
\text { after } \\
\text { Treatment } \\
\text { (mth.) }\end{array}$ & $\begin{array}{l}\text { Details of Side, } \\
\text { Previous Pneumothorax, etc. }\end{array}$ & $\begin{array}{c}\text { Time since } \\
\text { Last Episode } \\
(\text { yr.) }\end{array}$ & $\begin{array}{l}\text { Final } \\
\text { Treatment }\end{array}$ \\
\hline 62 & $\begin{array}{l}\text { Thoracoscopy } \\
\text { and poudrage }\end{array}$ & 2 & $\begin{array}{r}60 \\
21 \\
1\end{array}$ & $\begin{array}{l}\text { Same side; } 2 \text { on opposite side; } 3 \text { previous episodes } \\
\text { Same side; } 2 \text { previous episodes } \\
\text { Same side }\end{array}$ & $\begin{array}{l}2 \frac{1}{2} \\
2 / 12 \\
1\end{array}$ & $\begin{array}{l}\text { Rest } \\
\text { Poudrage }\end{array}$ \\
\hline 44 & Bed rest only & 5 & $\begin{array}{r}24 \\
24 \\
3 \\
3 \\
1\end{array}$ & $\begin{array}{l}\text { ? side } \\
\text { Same side; } 3 \text { previous episodes; asthma since } \\
\text { infancy } \\
\text { Same side; } 7 \text { recurrences; } 3 \text { previous episodes; } \\
\text { chronic bronchitis } \\
\text { Same side; } 2 \text { previous episodes; chronic bronchitis } \\
\text { Opposite side }\end{array}$ & $\begin{array}{l}3 \frac{1}{2} \\
4 \\
3 \\
\text { No follow-up }\end{array}$ & $\begin{array}{l}\text { Thoracotomy } \\
\text { Rest }\end{array}$ \\
\hline 18 & $\begin{array}{l}\text { Intercostal } \\
\text { tube }\end{array}$ & 3 & $\begin{array}{l}8 \\
3 \\
1\end{array}$ & $\begin{array}{l}\text { Same side; further bilateral recurrence } 1 \ddagger \text { and } \\
2 \text { years later } \\
\text { Same side } \\
3 \text { more on same side; } 5 \text { on opposite side; } \\
2 \text { previous episodes; developed pulmonary } \\
\text { tuberculosis }\end{array}$ & $\begin{array}{l}3 \\
1 \frac{1}{2} \\
2\end{array}$ & $\begin{array}{l}\text { Poudrage } \\
\text { Rest } \\
\text { Poudrage (L); } \\
\text { resection (R) }\end{array}$ \\
\hline 14 & Thoracotomy & 1 & 12 (approx.) & ? side; chronic bronchitis & 5 & Rest \\
\hline 6 & $\begin{array}{l}\text { Camphor } \\
\text { pleurodesis }\end{array}$ & 2 & 5 & $\begin{array}{l}2 \text { more on same side; } 3 \text { on opposite side; } \\
4 \text { previous episodes; developed pulmonary } \\
\text { tuberculosis } \\
\text { Same side; } 2 \text { previous episodes, including } \\
\text { haemopneumothorax }\end{array}$ & $1 \frac{1}{2}$ & $\begin{array}{l}\text { Resection (R) } \\
\text { (Pul. T.B.) } \\
\text { Thoracoscopy } \\
\text { and poud- } \\
\text { rage }\end{array}$ \\
\hline
\end{tabular}

TABLE XII

NINE CASES OF CHRONIC PNEUMOTHORAX

\begin{tabular}{|c|c|c|c|}
\hline $\begin{array}{r}\text { No. of } \\
\text { Patients }\end{array}$ & Treatment & $\begin{array}{l}\text { Duration } \\
\text { (mth.) }\end{array}$ & Outcome \\
\hline $\begin{array}{l}2 \\
3 \\
2 \\
2\end{array}$ & $\begin{array}{l}\text { Thoracotomy and decortication } \\
\text { Bed rest and aspiration of air } \\
\text { Aspiration, thoracoscopy and } \\
\text { pleurodesis, } \frac{1}{2} \% \mathrm{AgNO}_{3} \text {, kaolin }\end{array}$ & & \\
\hline $\begin{array}{l}1 \\
2 \\
2 \\
1 \\
2 \\
1\end{array}$ & & $\begin{array}{c}3 \\
4 \\
5 \\
8 \\
12 \\
5 \\
\mathrm{yr}\end{array}$ & \\
\hline $\begin{array}{l}8 \\
1\end{array}$ & & & $\begin{array}{l}\text { recurrence } \\
\text { st to follow-up }\end{array}$ \\
\hline
\end{tabular}

TABLE XIII

\section{LATER DEVELOPMENT OF ACTIVE TUBERCULOSIS}

\begin{tabular}{|c|c|c|}
\hline Male & 30 & $\begin{array}{l}\text { L. pneumothorax May } 1959 \\
\text { Bilateral apical disease then }\end{array}$ \\
\hline Male & 51 & $\begin{array}{l}\text { R. pneumothorax March } 1959 \\
\text { Infiltration R.U.L. later } \\
\text { bilateral }\end{array}$ \\
\hline Male & 32 & $\begin{array}{l}\text { R. pneumothorax July } 1957 \\
\text { Calcific bilateral U.L. lesions }\end{array}$ \\
\hline Male & 16 & $\begin{array}{l}\text { R. pneumothorax February } \\
1959 \\
\text { Apical bulla at thoracoscopy } \\
\text { Re-admitted January } 1960 \\
\text { with haemoptysis } \\
\text { Infiltration R.U.L. }\end{array}$ \\
\hline Male & 28 & $\begin{array}{l}\text { Sept. } 1954 \text { to Oct. } 1957 \text {; } \\
6 \text { on right, } 4 \text { on left } \\
\text { Progressive R.U.L. infiltra- } \\
\text { tion Oct. } 1957 \text { to Jan. } 1958 \\
\text { R. resection of tuberculous } \\
\text { disease June } 1958 \\
\text { L. throcotomy and pleuro- } \\
\text { de:is January } 1959\end{array}$ \\
\hline
\end{tabular}

There have been no recurrences in the eight patients followed over a mean period of 9.1 years. In all patients the chronic pneumothorax was the first episode. Weight loss was a fairly frequent symptom ( 3 patients), as noted by Brock (1948).

Development of Tuberculosis.-Five patients were subsequently found to have active tuberculosis (Table XIII). In three patients radiological upper lobe disease was present on admission at the time of the initial pneumothorax. The sputum was then negative but subsequently became positive. In two patients infiltration of the right upper lobe subsequently developed some time after the initial spontaneous pneumothorax, at which time the radiograph was clear.

Period in Hospital.- As lung re-expansion is usually complete within 12 to 24 hours after thoracoscopy and poudrage, it had been expected that the average stay in hospital of these patients would prove considerably shorter than that of the patients treated by bed rest alone. This was not the case (Table IX), although many patients were in fact discharged seven to 12 days after treatment. Several, however, were retained in hospital for periods of up to 100 days for investigation regarding tuberculous activity, social reasons, or treatment of chronic bronchitis. When these considerations were excluded, a period of 10 to 12 days in hospital and return to work one week later was the rule. In contradistinction, the patients treated by other methods spent longer in hospital. 


\section{DISCUSSION}

Spontaneous pneumothorax is less rare than the published records suggest, as many cases have not been reported. According to the data of WynnWilliams (1957), the incidence in the United Kingdom is five per 100,000 per year.

The commonest complication of spontaneous pneumothorax is recurrence. As noted in Table XIV, recurrences have been reported in the literature in 5 to $50 \%$ of cases. It is likely that the higher figure is more accurate in view of the relatively short follow-up period and the exclusion of unproved recurrences. As Maxwell (1954) stated, it appears as likely as not that a recurrence will develop in any one individual. Most authors agree that most of these recurrences occur in the first two to three years, but first recurrences from 10 to 21 years after the initial episode have been reported by Myers (1954) and by Perry (1939). In some patients there appears to be a special tendency to recur on many occasions, either on the same or the opposite side. In the present series one patient had 10 proved episodes, and there are several examples of 20 or more recurrences in the literature. Shefts, Gilpatrick, Swindell, and Gabbard (1954) state that 10 to $12 \%$ of pneumothoraces will be bilateral, usually alternating, but occasionally simultaneous. In the present series multiple pneumothoraces occurred in $29 \%$ of patients and the episodes were bilateral in $10 \%$.

The insidious onset of symptoms in $20 \%$ of patients indicates that this disease has not always the dramatic onset usually expected with pneumothorax. Presumably a slow leak is the explanation in these patients.

As has been accepted for some years, activity seems to play little part in the causation of the pneumothorax, and it would seem quite unreasonable to forbid a patient to return to his former activity following recovery from the pneumothorax. There is also no evidence that prolonged bed rest is beneficial while the pneumothorax is present.

Tuberculosis.-Five patients $(3 \%)$ in this series developed pulmonary tuberculosis. There was no radiological or other evidence of this disease at the time of the pneumothorax in two of these patients. In the others, radiological fibrocalcific lesions were present, although routine sputum cultures were negative, and only one patient had previously been treated for tuberculosis. The possibility, therefore, that a spontaneous pneumothorax may be an unusual presentation of pulmonary tuberculosis must be considered. In practice there is every reason to see these patients occasionally for review. As Lambert (1956) suggested, the swing of medical opinion to a non-tuberculous aetiology since the paper of Kjaergaard has been too extreme. In Lambert's 53 cases of pneumothorax simplex, six had radiological evidence of tuberculosis, and there were minor non-specific apical shadows in eight. This association was greater than could be explained by chance.

TREATMENT.-The most controversial aspect of spontaneous pneumothorax concerns the necessity for some form of active treatment and the type of treatment to be employed. The several opinions available suggest that there is no ideal treatment, and this no doubt is partly due to differences in the aetiology of the pneumothorax. Opinion may be coloured by the availability of a specialized thoracic centre and by whether the clinician in charge is a physician or a surgeon. Many have now agreed that a more active approach is justified on the grounds of accelerating the patient's discharge from hospital and attempting to prevent future recurrences. If an active form of treatment is felt

TABLE XIV

REVIEW OF SELECTED LITERATURE

\begin{tabular}{|c|c|c|c|c|c|}
\hline Author & $\begin{array}{l}\text { No. of } \\
\text { Patients }\end{array}$ & $\begin{array}{c}\text { Patient } \\
\text { Recurrences }\end{array}$ & Chronic & $\begin{array}{l}\text { Developed } \\
\text { Pulmonary } \\
\text { Tuberculosis }\end{array}$ & $\begin{array}{l}\text { Follow-up } \\
\text { (yr.) }\end{array}$ \\
\hline $\begin{array}{l}\text { Kjaergaard (1932) } \\
\text { Perry (1939) } \\
\text { Melrose (1950) } \\
\text { Shefts, Gilpatrick, Swindell, } \\
\text { and Gabbard (1954) }\end{array}$ & $\begin{array}{c}51 \\
85 \\
70 \\
114(1949-1952)\end{array}$ & $\begin{array}{c}7(14 \%) \\
4(4 \cdot 7 \%) \\
58(50 \%)\end{array}$ & 6 & $\begin{array}{l}1(2 \%) \\
0(0 \%) \\
4(6 \%)\end{array}$ & $\begin{array}{l}3-18 \\
1-13 \\
1-10 \\
2-5\end{array}$ \\
\hline $\begin{array}{l}\text { Crowther (1955) (review of } \\
\text { literature since 1932) } \\
\text { Myers (1954) } \\
\text { Marrangoni, Storey, and } \\
\text { Geib (1955) }\end{array}$ & $\begin{array}{r}61(1948-1953) \\
519(1932-1953) \\
123(1934-1953) \\
80(1952-1954)\end{array}$ & $\begin{array}{l}14(23 \%) \\
17(14 \%) \\
12(15 \%)\end{array}$ & 11 & $\begin{array}{l}1(2 \%) \\
14(3 \%) \\
3(3 \%)\end{array}$ & $\begin{array}{l}\frac{1}{2}-5 \\
1-20 \\
1-3\end{array}$ \\
\hline $\begin{array}{l}\text { Crenshaw }(1950) \\
\text { Gaensler (1956) (review of } \\
\text { literature since 1944) }\end{array}$ & $\begin{array}{r}86(1915-1950) \\
1,080(1944-1955)\end{array}$ & $\begin{array}{c}23(27 \%) \\
245(22 \cdot 7 \%)\end{array}$ & 10 & & $\begin{array}{c}\frac{1}{2}-5 \\
1-2 \\
\text { (mainly) }\end{array}$ \\
\hline $\begin{array}{l}\text { Wynn Williams (1957) } \\
\text { Sochocky (1960) } \\
\text { Present series }\end{array}$ & $\begin{array}{r}70(1947-1956) \\
58(1952-1958) \\
150(1944-1960)\end{array}$ & $\begin{array}{l}7(10 \%) \\
19(33 \%) \\
43(29 \%)\end{array}$ & 9 & $5(3 \%)$ & $1-10$ \\
\hline
\end{tabular}


desirable, the decision will usually rest between (1) the insertion of an intercostal tube and underwater seal with or without suction; (2) thoracoscopy and pleurodesis; or (3) thoracotomy. Air aspiration is probably of benefit only in slightly reducing the period of bed rest in hospital. The use of an intercostal tube may stimulate some degree of pleural adhesion, but on general principles recurrence would seem more probable after this procedure than after other forms of pleurodesis or thoracotomy. In certain patients with obvious large bullae or large bronchopleural fistulae, thoracotomy will be clearly indicated. In the others it would seem reasonable that some form of artificial pleurodesis would be preferable to a major surgical procedure, provided that the method of pleurodesis can be shown to be safe and effective.

Spengler in 1906 first attempted pleurodesis with hypertonic glucose and later with $5 \%$ silver nitrate. Bethune (1935), after extensive experimental work in animals and man, advised pleural insufflation with iodized talc and considered this the most satisfactory form of pleurodesis. Singer, Jones, and Tragerman (1941) confirmed this opinion after a large number of animal experiments. In a 10-year follow-up study of patients treated with pure talc pleurodesis, the French workers Bernard and Meyer (1951) found no significant complications such as talc granulomata or fibrothorax. Since 1906 many substances have been introduced into the pleural cavity to produce artificial pleurodesis, either physically, e.g., talc, or chemically, e.g., silver nitrate. These substances include talc, kaolin, silver nitrate, hypertonic glucose, oil of gomenol, iodized oil, blood, camphor, gases, killed bacteria, India ink, ether, and even rubber solution. It appears that silver nitrate and plain or iodized talc have been used most extensively, although many workers have abandoned silver nitrate because of severe pleural pain. There is no large published series of patients treated with iodized talc poudrage. Marrangoni, Storey, and Geib (1955) advised plain talc poudrage for large or recurrent pneumothoraces and report 25 cases with a short followup. Crowther (1955) advised thoracoscopy and iodized talc pleurodesis and reports on 13 patients.

Many thoracic surgeons feel that thoracotomy is advisable for all patients with chronic and recurrent episodes, as well as those with obvious bullae. Gaensler (1956) condemns pleurodesis on the grounds that iodized talc is " useless, uncertain, or dangerous." He states that severe pain, prolonged stay in hospital, febrile reactions, shock, and gross residual pleural thickening are the usual results. However, he gives few details of such patients. On the basis of nine cases of recurrent pneumothorax followed for periods of only one to 15 months after operation, he strongly advocates thoracotomy and parietal pleurectomy as the treatment of choice for all such cases. His comments regarding iodized talc pleurodesis are certainly not borne out by the results of the present series. In our view, it appears unjustifiable to resort to major surgery with its significant complication rate unless an obvious indication is present. Shefts et al. (1954) also condemn the use of plain talc, after reporting on five patients in their series of 114 patients. The fact that Gaensler states that multiple small bullae or other obvious cause can be demonstrated at operation or thoracoscopy in $90 \%$ of cases of recurrent pneumothorax is no argument against pleurodesis if, in fact, this procedure can be shown to be effective. This we believe to be the case. Baronofsky, Warden, Kaufman, Whatley, and Hanner (1957) carried the surgical view to extremes when they advised double thoracotomy at the time of first spontaneous pneumothorax on the grounds that there is a 10 to $15 \%$ chance of a pneumothorax appearing on the opposite side.

A mortality rate of $20 \%$ has been quoted in haemopneumothorax (Holloway, Speir, and Sadler, 1952). This indicates the serious nature of this complication. Thoracotomy will often be necessary, although two out of four patients in the present series did well without thoracotomy and in neither was there evidence of significant radiological pleural fibrosis.

There were nine cases of chronic pneumothorax. Thoracotomy was performed in only two patients, and the others did well despite the firm surgical opinion of Gaensler (1956) that thoracotomy is necessary. Brock (1948) felt that pleurodesis was logical and advised silver nitrate. It is obvious that the basic pathology of the chronic pneumothorax will influence the results of treatment, and it is unlikely, for example, that pleurodesis will succeed if a large epithelialized bronchopleural fistula is present. However, it has certainly been unnecessary to subject the majority of our patients to major surgery.

A recent annotation in the British Medical Journal (Annotation, 1958) discusses the indications for active treatment, and these views are very similar to our own and to those of Bernard and Meyer (1951) and Shefts et al. (1954). Conservative therapy is probably indicated for first episodes and certainly if the spontaneous pneumo- 
thorax is small and uncomplicated by associated chest disease. It seems unnecessary to confine such patients to bed. However, as Maxwell (1954) suggested, there is a $50 \%$ chance of a recurrence, and a more active approach may well be indicated, especially if a patient is unduly apprehensive about the possibility of recurrence. If little reexpansion has occurred after a 10 to 14 day period, an active form of treatment should be advised, preferably in a thoracic centre. Associated chest disease, such as emphysema and pneumoconiosis, especially in patients over 40 , may provide an urgent indication for active treatment in the first episode of pneumothorax. Not infrequently such pneumothoraces may be relatively small, although considerable respiratory distress may be evident. All recurrent cases should be treated actively. Few would disagree that active treatment is necessary for simultaneous bilateral pneumothorax, haemopneumothorax, tension pneumothorax, chronic pneumothorax, and those patients with large cysts and bullae. Our present experience indicates that thoracoscopy and poudrage with iodized talc is safe and effective and, as far as we are aware, has not led to any serious complications. It seems unnecessary to resort to major surgery with its inherent risks except where a clearly defined indication is present, such as large bullae or cysts, certain cases of chronic pneumothorax with large bronchopleural fistulae or gross pleural thickening, and some cases of haemopneumothorax. In all other cases after any necessary emergency decompression with an intercostal catheter rather than the Foster-Carter needle (for which purpose it was never intended) a thoracoscopy and poudrage with iodized talc under general anaesthesia is a very satisfactory form of treatment. The patient can then look forward to an early discharge from hospital, early return to work, and can be given a guarantee that no recurrence will develop.

It is apparent that prolonged observation of the patients in this series is necessary to confirm our present views and a further review of these patients is planned in approximately five years.

\section{SUMMARY}

A series of 150 patients with spontaneous pneumothorax treated between 1944 and 1960 is presented.

Sixty-two of these patients have been treated with iodized talc pleurodesis combined with thoracoscopy. So far only three recurrent pneumothoraces have developed, of which one was very trivial, and there have been no significant complications from the treatment.

A more active approach is necessary in the treatment of spontaneous pneumothorax with the aim of reducing the period in hospital and preventing future recurrences which will develop in approximately $50 \%$ of patients. Thoracotomy seems unnecessary and undesirable unless a firm indication is present.

In view of the slight possibility that a spontaneous pneumothorax may result from an early tuberculous lesion, regular follow-up is advisable.

We wish to thank the medical and surgical consultants of Sully and Llandough Hospitals for allowing us to review this series of patients under their care. The views expressed are largely personal but correspond fairly closely to the general opinions held by the combined team of surgeons and physicians.

We are grateful to the many chest physicians in South Wales and elsewhere who helped to trace and have radiographs taken of these patients, and for the cooperation and help we received from family practitioners and from the patients themselves.

Mr. Gumley, acting nursing tutor, rendered valuable assistance in the collection and analysis of data.

We thank Miss P. Edwards and her staff at Sully Hospital and Miss L. Smyth at Perth Chest Hospital for valuable secretarial assistance.

Finally, we wish to thank Dr. H. M. Foreman and Mr. Dillwyn Thomas for reading this paper before submitting it for publication.

\section{REFERENCES}

Annotation (1958). Brit. med. J., 1, 1347.

Baronofsky, I. D., Warden, H. G., Kaufman, J. L., Whatley, J., and Hanner, J. M. (1957). J. thorac. Surg., 34, 310

Bernard, E., and Meyer, A. (1951). Dis. Chest, 19, 641.

Bethune, N. (1935). J. thorac. Surg., 4, 251.

Brock, R. C. (1948). Thorax, 3, 88.

Crenshaw, G. L. (1950). Dis. Chest, 17, 369.

Crowther, J. S. (1955). Tubercle (Lond.), 36, 265.

Gaensler, E. A. (1956). Surg. Gynec. Obstet., 102, 293.

Holloway, J. B., Speir, R. C., and Sadler, R. N. (1952). Amer. Surg. 18,518 .

Itard, J. E. (1803). Thesis, Paris.

Kjaergaard, H. (1932). Acta med. scand. suppl., 43.

Laennec, R. T. (1826). Traité de L'Auscultation Médiate, 2nd ed. Chaudé, Paris.

Lambert, H. P. (1956). Tubercle (Lond.), 37, 207

Marrangoni, A. G., Storey, C. F., and Geib, P. O. (1955). Amer. Rev. Tuberc., 72, 257.

Maxwell, J. (1954). Thorax, 9, 10.

Melrose, H. G. (1950). Glasgow med. J., 3!, 263.

Myers, J. A. (1954). Dis. Chest, 26, 420.

Palmer, J. P., and Taft, R. B. (1931). J. Amer. med. Ass., 96, 653.

Perry, K. M. A. (1939). Quart. J. Med., 8, 1.

Shefts, L. M., Gilpatrick, C., Swindell, H., and Gabbard, J. G. (1954). Dis. Chest, 26, 273.

Singer, J. J., Jones, J. C., and Tragerman, L. J. (1941). J. thorac. Surg., 10, 251.

Sochocky, S. (1960). Brit. J. clin. Pract., 14, 12.

Spengler, L. (1906). Bruhs' Beitr. klin. Chir., 49, 68.

Wynn-Williams, N. (1957). Thorax, 12, 253. 